\title{
Major problems, current characteristics and future career plans of obstetrics and gynecology residents in Turkey
}

\section{Türkiye'de kadın hastalıkları ve doğum asistanlığ mevcut durum, karşılaşılan başlıca sorunlar ve kariyer planları}

\author{
(1) Selçuk Erkılınç1, (1) Murat Yassa ${ }^{2}$, (1) Buğra Coşkun ${ }^{3}$, (1) Onur İnce ${ }^{4}$, (1) Ateş Karateke \\ ${ }^{1}$ Isparta City Hospital, Clinic of Gynecologic Oncology, Isparta, Turkey \\ 2 Bartın State Hospital, Clinic of Obstetrics and Gynecology, Bartın, Turkey \\ ${ }^{3}$ Liv Hospital, Clinic of Obstetrics and Gynecology, Ankara, Turkey \\ ${ }^{4}$ Kütahya University of Health Sciences, Faculty of Medicine, Department of Obstetrics and Gynecology, Kütahya, Turkey \\ 5İstanbul Medeniyet University Faculty of Medicine, Department of Obstetrics and Gynecology, İstanbul, Turkey
}

\begin{abstract}
Objective: To evaluate the current problems and future career plans of obstetrics and gynecology residents in Turkey.

Materials and Methods: In this cross-sectional study, a survey was conducted with 143 trainees from 25 cities in different regions of Turkey. The questionnaire, which was sent via e-mail to all available trainees, consisted of four parts: information on hospitals, number and variety of surgical interventions, scientific activities, and current problems. Descriptive statistics were used to analyze participants' responses.

Results: The mean number of trainees in each hospital was 24 in education and research hospitals and 15 in university hospitals ( $\mathrm{p}<0.001)$. Perinatology, oncology, and infertility clinics were present in about $70 \%$ of the hospitals, and there was no difference in this regard between public and university hospitals. Most trainees (68.5\%) complained about being alone in an outpatient clinic. Third-year trainees from training and research hospitals performed a significantly higher number of vaginal births than those at universities $(\mathrm{p}=0.035)$. Most trainees complained about their workload during their residency in both training and research hospitals (74.4\%) and university hospitals (66\%). The three most common plans for the future were to attend a subspecialty program in the field of obstetrics and gynecology (28\%), to pursue an academic career (23.1\%), and to work in a private hospital (21\%).

Conclusion: Extremely long work hours, excessive workload, many monthly duties, and lack of supervision at outpatient clinics were found to be the major problems of the obstetrics and gynecology residents in Turkey. The most common future plan of the residents was to attend a subspecialty program in the field of obstetrics and gynecology.

Keywords: Obstetrics and gynecology department, hospital, residency, training

Öz

Amaç: Türkiye'de kadın hastalıklanı ve doğum asistanlı̆̆ının güncel sorunlarını ve özelliklerini değerlendirmektir.

Gereç ve Yöntemler: Bu anket, Türkiye’nin her bölgesinden, 25 ilden araştırma görevlisi üzerinde yapıldı. Tüm katılımcılara e-posta ile bir anket gönderildi. Bu anket hastane bilgileri, çeşitli cerrahi müdahalelerin sayısı, bilimsel aktiviteler ve güncel problemler olmak üzere dört bölümden oluşmaktaydı. Katılımcı yanıtları analiz etmek için tanımlayıcı istatistikler kullanıldı.

Bulgular: Ortalama asistan sayısı eğitim ve araştırma hastanelerinde 24 iken üniversite hastanelerinde 15 olarak saptandı (p<0,001). Perinatoloji, onkoloji ve infertilite klinikleri tüm hastanelerin \% 70'inde mevcut olup gruplar arasında anlamlı bir fark izlenmedi. Katılımcıların çoğu $(\% 68,5)$ poliklinikte yalnız kaldıklarından şikayetçiydi. Eğitim ve araştırma hastanelerinde 3. yıl araştırma görevlilerinin üniversite hastanelerindekilere oranla daha fazla sayıda vajinal doğum yaptırdıkları gözlendi ve bu sonuç istatistiksel olarak anlamlıydı ( $\mathrm{p}=0,035)$. Katılımcılar en fazla iş yoğunluğundan şikayetçi olup eğitim ve araştırma hastanelerinde ve üniversite hastanelerinde bu oran sırasıyla \%74,4 ve \%66 idi. Gelecek için en çok tercih edilen planlar kadın hastalıkları ve doğum yan dal programına katılmak, akademik kariyer yapmak ve özel bir hastanede çalışmak olup bu oranlar sırasıyla \%28, \%23,1, \%21 saptanmıştır.
\end{abstract}

PRECIS: In this study, the current problems and future expectations of obstetrics and gynecology residents across the nation were evaluated.

Address for Correspondence/Yazışma Adresi:Selçuk Erkılınç, MD,

Isparta City Hospital, Clinic of Gynecologic Oncology, Isparta, Turkey

Phone: +90 2462134444 E-mail: selcukerkilinc@hotmail.com ORCID ID: orcid.org/0000-0002-6512-9070

Received/Gelis Tarihi: 18.11.2018 Accepted/Kabul Tarihi: 02.09.2019

${ }^{\circ}$ Copyright 2019 by Turkish Society of Obstetrics and Gynecology

Turkish Journal of Obstetrics and Gynecology published by Galenos Publishing House. 
Sonuç: Anket sonuçlarına göre kadın hastalıkları ve doğum asistanlarının en önemli problemleri; uzun çalışma saatleri, fazla iş yükü, aylık nöbet sayısının fazlalığı, polikliniklerde denetimsiz çalışmak olarak saptandı. Asistanların en yaygın gelecek planı, kadın hastalıkları ve doğum alanında bir yan dal programına katılmak olarak tespit edildi.

Anahtar Kelimeler: Kadın hastalıkları ve doğum bölümü, hastane, tıp asistanlığı, eğitim

\section{Introduction}

Turkish Trainees of Obstetrics and Gynecology is an organization that has collaborated with the European Board College for Obstetrics and Gynecology and European Network Trainees of Obstetrics and Gynecology (ENTOG) since 2010(1). This collaboration facilitated a mutual understanding of educational models across Europe. There are advantages and disadvantages of training in obstetrics and gynecology (OBGYN) specialism in Turkey. The population of Turkey is about 80 million $^{(2)}$ and the annual number of trainees in OBGYN is about 1200 . The low trainee to population ratio results in long working hours and fatigue. On the other hand, the upside of this low ratio is the high number of operations per trainee ${ }^{(3)}$. Training in OBGYN takes place in two types of hospitals in Turkey. Training and research hospitals are public hospitals that are affiliated to the ministry of health and render most of the healthcare service to the general population ${ }^{(4)}$. University hospitals are self-governing hospitals that deal with more complex cases and their work load is lower than public hospitals. Despite some technical limitations, these two types of hospitals have nationwide coverage, even in rural areas. There are no operational national mobilization and external rotation programs, so trainees have to complete all of their rotations in the same hospital. To the best of our knowledge, there is no study evaluating current problems and characteristics of OBGYN training in Turkey. This survey evaluates the current conditions and issues regarding OBGYN residency. We believe that identifying the issues is the first step to developing the relevant solutions.

\section{Materials and Methods}

The study was conducted in cross-sectional design. The OBGYN training institutions in Turkey were determined relying on the information from Measuring, Selection and Placement Center's web page ${ }^{(5)}$. Fifty-six institutions were identified. The names of trainees were collected from the webpages of the 44 of the institutions that provided this information. The contact information of the trainees was collected through social networks (Facebook/tjodasistan). A survey was sent via e-mail to 568 trainees whose contact information was available. One hundred forty-three of the 568 trainees $(25.3 \%)$ responded to the survey. These 143 trainees were from 25 cities from all the different regions of Turkey. Informed consent was obtained from these trainees. The survey was an online multiple choice questionnaire. The questionnaire consisted of four parts, concerning information on hospitals, number and variety of surgical interventions, scientific activities and problems. More specifically, the questions asked for the city, year of training, presence of departments of gynecologic oncology, perinatology, infertility, whether the hospital was public or university, the number of trainees at the hospital, number of deliveries per day, number of night shifts, supervision at outpatient clinics and operations, time of first deliveries and cesarean section, number of operations in gynecology, perinatology, infertility and oncology, utility of rotations to other specialties, number of scientific meetings, and number of international meetings. The questions on the problems of trainees included day-after duties, workload, working hours, mobbing, lack of support for scientific activities, lack of supervision in outpatient clinics, vacations, satisfaction with salary, and future plans. The data were collected using Google documents and analyzed with the IBM SPSS statistics ver. 21.0 (IBM Corp., Armonk, NY) software package. Continuous data are presented as mean \pm standard deviation or median (minimum-maximum), and categorical data are reported as number and percentage. Continuous data were compared using the Independent Sample t-test or MannWhitney U tests. Categorical data were compared using the chisquare test.

\section{Results}

One hundred forty-three trainees from 56 institutions, 27 university hospitals and 29 education and research hospitals (a type of public hospital that provides training to residents), were included in the study. The percentage of trainees with $1,2,3$, and 4 years of training were $16 \%, 35 \%, 37 \%$, and $55 \%$, respectively. The mean number of trainees in training and research hospitals and university hospitals was 24 and 15 respectively. Although the median number of births per day was higher in public hospitals than in university hospitals, there was no significant difference between university and public hospitals (20 vs. 10; p>0.05). Perinatology, oncology and infertility clinics were present in about $70 \%$ of the hospitals and the difference between public and university hospitals was not significant. Only about $7 \%$ of the trainees could do postcall off. The trainees preferred to be a trainee in OBGYN as a first choice with a rate of $61 \%$. Most of the trainees complained about being alone in outpatient clinics, with $68.5 \%$ reporting no supervision. The first labor during training was performed in the first month by $70 \%$ of the trainees. The comparison of the data between public and university hospitals is shown in Table 1 . The number of operations performed by the trainees under supervision is shown in Table 2. All operation rates were found to be similar between the two types of hospitals except for vaginal births for $3^{\text {rd }}$ year trainees. Trainees at public hospitals in the $3^{\text {rd }}$ year performed a significantly higher number of vaginal births than those at university hospitals. About half of the trainees assessed the utility of rotations with the lowest 
score. The trainees ranked pathology as the branch with the least utility during training. The utility rates of the other rotations from the point of view of the trainees are given in Figure 1. The trainees in training and research hospitals and university hospitals complained about the workload at rates of $74.4 \%$ and $66 \%$, respectively. Excessive numbers of nightshifts bothered $46 \%$ and $39 \%$ of trainees in public hospitals and university hospitals, respectively. Trainees also identified mobbing as a problem at $30 \%$ and $22 \%$ in public and university hospitals, respectively. Working alone in an outpatient clinic without a supervisor was identified as a problem by $61 \%$ and $58.5 \%$ of the trainees in public and university hospitals. Problems related to work and their review by the trainees are given in Table 3. If given the chance to choose their specialty again, OBGYN remained the most popular choice of the trainee at $25.2 \%$. Dermatology, urology, and pathology specialties were

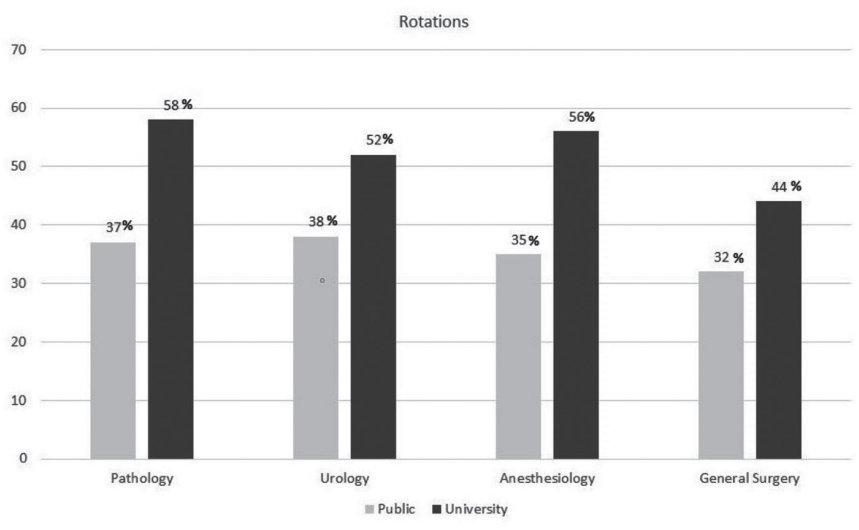

Figure 1. Percentage of trainees scoring rotations as inefficient chosen by $7.2 \%, 4.2 \%$, and $4.2 \%$ of the trainees, respectively. The least popular specialties were cardiovascular surgery, infectious diseases, and emergency medicine ( $0.7 \%$ for each) as demonstrated in Figure 2. After completing the residency, the three most common preferences for the future career plans were to attend a subspecialty fellowship program in the field of OBGYN, to pursue an academic career, and to work in a private hospital (28\%, 23.1\%, and 21\%, respectively). Seven percent of the trainees, on the other hand, planned to pursue a career in another specialty. With regard to future places of work, 15.4\% of the residents were planning to work in a public hospital, and $5.6 \%$ were planning to have their own private clinic, as demonstrated in Figure 3.

\section{Discussion}

This study highlights the main problems of OBGYN residents in Turkey by providing objective baseline data that can be compared with other European countries. The evidence points to an excessive workload on OBGYN residents with the benefit of an early start to vaginal/cesarean births and performing a large number of gynecologic surgeries. Half of the (54.6\%) trainees planned to work in the private sector, and $7 \%$ planned to switch to another specialty. The number of residents in OBGYN training programs is inadequate to meet demands of the growing adult female population, and the current shortage of OBGYNN residents is projected to worsen in the future(6). Residents were found to experience significantly more burnout, have a higher risk for psychological morbidity, and lower career satisfaction rates relative to attending surgeons ${ }^{(7)}$. Becker et al. ${ }^{(8)}$ assessed burnout and depression rates in 118 residents from 23 different randomly selected OBGYN residency programs in the

Table 1. Demographic data of hospitals and residents in obstetrics and gynecology in Turkey

\begin{tabular}{|c|c|c|c|c|}
\hline & Whole group & $\begin{array}{l}\text { Training and research } \\
\text { hospitals }(n=90)\end{array}$ & University hospitals ( $\mathrm{n}=53$ ) & $P$ value \\
\hline Number of trainees (mean $\pm \mathrm{SD}$ ) & $19(1-90)$ & $24(1-90)$ & $15(1-30)$ & $<0.001$ \\
\hline Number of faculty & $6(1-25)$ & $7(1-30)$ & $6(1-30)$ & 0.188 \\
\hline Perinatology & $92(64)$ & $60(66)$ & $32(60)$ & 0.474 \\
\hline Gynecologic oncology & $110(76)$ & $78.8(71)$ & $39(73)$ & 0.467 \\
\hline Infertility/family planning & $86(60)$ & $55(61)$ & $31(58)$ & 0.860 \\
\hline Labor (per day) & $15(0-100)$ & $20(1-100)$ & $10(1-40)$ & 0.261 \\
\hline Shifts (per month) & $7(0-15)$ & $7(0-12)$ & $8(0-15)$ & 0.097 \\
\hline Every other day duty & $85(59)$ & $63.3(57)$ & $28(52)$ & 0.224 \\
\hline Post-duty off & $8(5)$ & $4(4.4)$ & $4(7.5)$ & 0.336 \\
\hline Supervision at outpatient clinic & $45(31)$ & $28(31)$ & $17(32)$ & 0.905 \\
\hline Supervision at surgery & $112(78)$ & $72(80)$ & $40(75)$ & 0.526 \\
\hline First normal labor at $1^{\text {st }}$ month of training & $99(69)$ & $65(72)$ & $34(64)$ & 0.312 \\
\hline First CS at $1^{\text {st }}$ month of training & $46(32)$ & $31(34)$ & $15(28)$ & 0.448 \\
\hline
\end{tabular}


United States. Almost 90\% of the residents were found to have moderate burnout and one-third showed signs of depression.

Working hours are known to be a powerful predictor of burnout, psychiatric morbidity, and decreased work-life balance ${ }^{(7)}$. Alston et al..$^{(9)}$ interviewed 226 medical students who stood up for an OBGYN residency position. The greatest concern about

Table 2. Number of operations performed by trainees under supervision Entire group

Normal labor

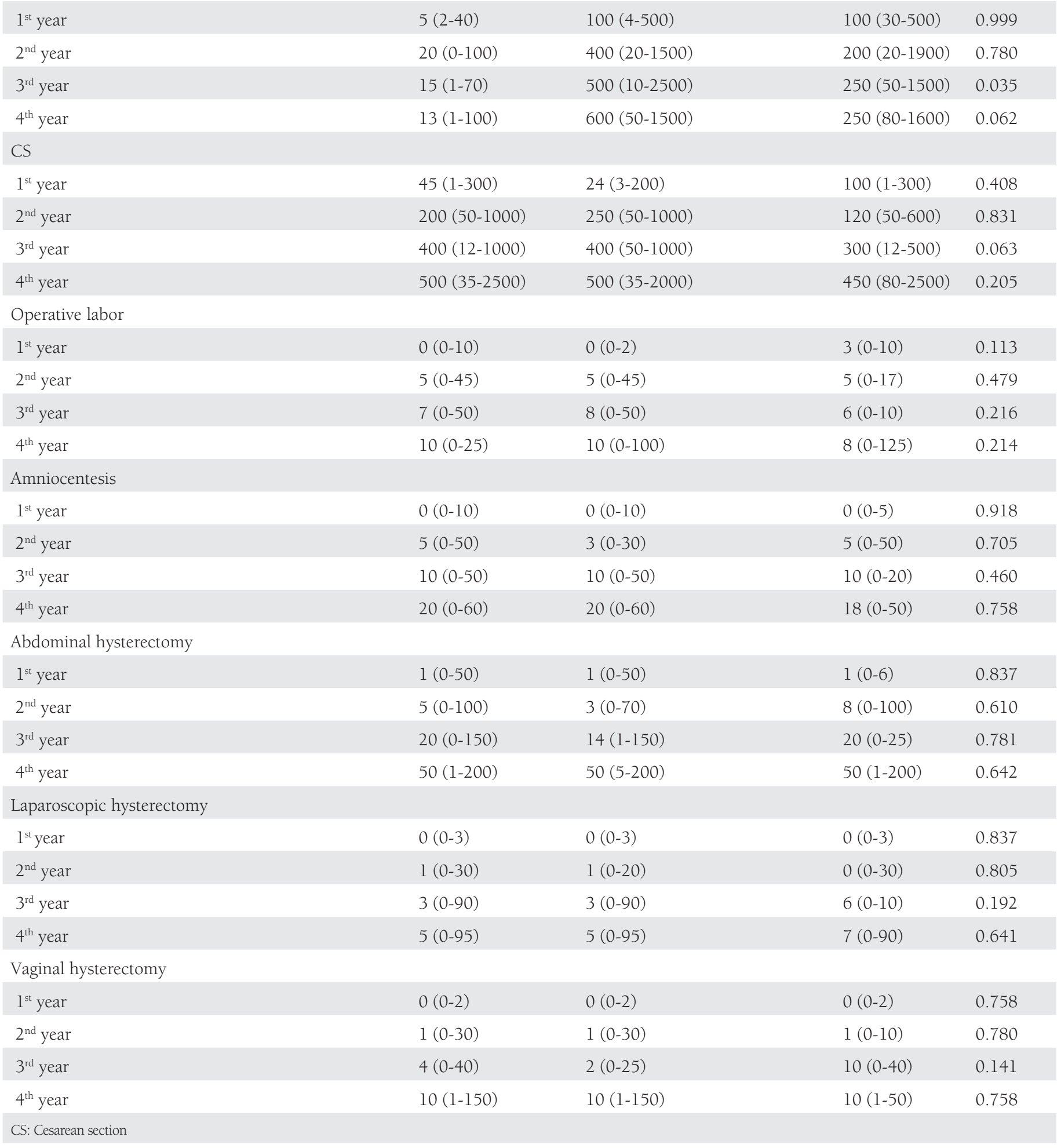


OBGYN was the long work hours for $65 \%$ of the students. The current study revealed that $59.4 \%$ of the residents had nightshifts every other day in their first half of the residency. Only $5.6 \%$ of the residents had the chance to return home after the in-hospital call. One-third of the residents claimed that they had no chance for a yearly vacation. An observational, descriptive, and cross-sectional study conducted in 25 different ENTOG member countries found the average number of weekly working hours for 6056 OBGYN trainees as 51.6 hours, with an average night-shift number of 5 (range, 2-9) per month ${ }^{(10)}$. The burnout effects, physiologic morbidities, and potential safety concerns caused by these extreme working hours are still unknown and need to be investigated. Impaired surgeon performance due to sleep deficiency has been associated with serious medical errors. However, it was hypothesized that home call design may compromise resident clinical experience and satisfaction, although it has allowed for compliance with

Table 3. Percentage of trainees who scored problems as most annoying

\begin{tabular}{|l|l|l|l}
\hline & Public & University & P value \\
\hline Too many duties & $42(46.7)$ & $21(39.6)$ & 0.413 \\
\hline Working hours & $56(62.2)$ & $30(56.6)$ & 0.507 \\
\hline Workload & $66(74.4)$ & $35(66)$ & 0.355 \\
\hline Number of faculty & $17(18.9)$ & $7(13.2)$ & 0.380 \\
\hline Mobbing & $27(30)$ & $12(22.6)$ & 0.340 \\
\hline Operations & $7(13.2)$ & $18(20)$ & 0.860 \\
\hline $\begin{array}{l}\text { No supervision at } \\
\text { outpatients clinic }\end{array}$ & $55(61)$ & $31(58.5)$ & 0.757 \\
\hline Medicolegal issues & $28(31)$ & $12(22.6)$ & 0.355 \\
\hline No vacation & $33(36.7)$ & $17(32.1)$ & 0.578
\end{tabular}

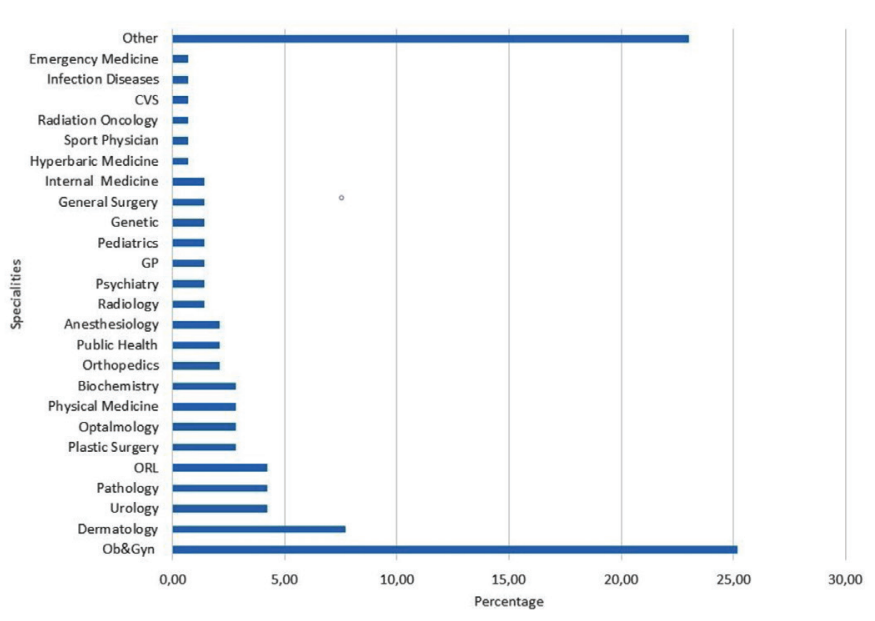

Figure 2. What would you choose if you had a chance to change your specialty?

Ob\&Gyn: Obstetrics gynecology, ORL: Otorhinolaryngology, CVS: Cardiovascular surgery duty hour requirements ${ }^{(11)}$. We believe that extending the duration of OBGYN residency may be better for training and work-life balance than transforming in-hospital calls into house calls. In this vein, ENTOG has officially suggested that the minimum duration of training should be at least five years to improve harmonization ${ }^{(10)}$. In an interview study, it was found that the most important factor in selecting an OBGYN residency among medical students was the overall surgical training, particularly training in laparoscopic surgery ${ }^{(12)}$. Cadish and Muffly ${ }^{(13)}$ conducted a retrospective cohort study of recent OBGYN residency graduates to estimate the average simple hysterectomy volume performed in the United States. It was found that recent graduates performed an average of 4 hysterectomies annually in their first five years after residency. The most common route was the abdominal route with $41.6 \%$, and the second common route was laparoscopy with $32.4 \%$. In the current study, a trainee primarily performed an average of 50 abdominal hysterectomies, 5 laparoscopic hysterectomies, and 10 vaginal hysterectomies in the last year before graduation. The number of performed surgeries during the residency is the main upside of the excessive work hours and night shifts. A recent study conducted in six different university in the United States revealed that $43 \%$ of residents were planning to enter private practice and only $19.4 \%$ of those were planning to pursue an academic career ${ }^{(14)}$. In the current study, comparable findings were observed with $44.6 \%$ of the residents planning to work in the private sector and $23.1 \%$ planning an academic career. The obstacles in the way of pursuing an academic career should be investigated further. In the present study, medicolegal issues were found to worry $31 \%$ and $22.6 \%$ of the residents in public and university hospitals, respectively. Current data suggest that medico-legal training during OBGYN residency is inadequate $e^{(15)}$. A large survey study showed that more than $20 \%$ of the fourth-year OBGYN residents had already been in a lawsuit ${ }^{(16)}$ and more than half of those indicated that they had not received adequate training on legal matters. In a prospective survey study, $35 \%$ of residents stated that they had been planning for a fellowship program only because of malpractice concerns. In Turkey, all procedures are under a specialist's

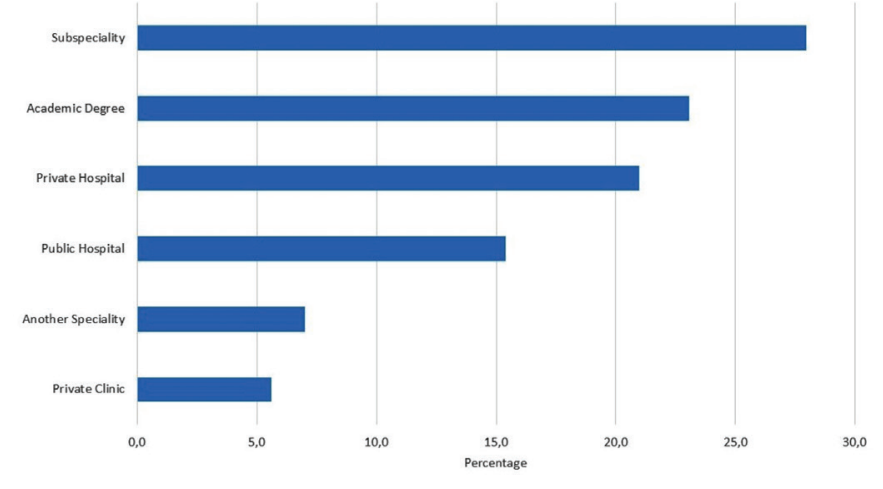

Figure 3. Future plans of residents in Turkey 
responsibility. However, malpractice insurance is still a crucial support for the residents. In Turkey, malpractice insurances are semi-subsidized, and should be encouraged more. This study is the first to objectively assess the problems and career plans of OBGYN residents in Turkey. Its major limitations are the lack of subgroup analysis for sex distribution and the low response rate. At the same time, the respondents were from 25 cities from all the different regions of Turkey, which bodes well for the representativeness of the sample.

Based on the analysis of the survey results, one-to-one interviews and concilium with the ENTOG, the following suggestions were identified in order to improve the job satisfaction, quality of training, burnout and depression levels, and liability and medicolegal preparedness:

- Minimum duration of OBGYN residency should be five years to improve harmonization with Europe and reduce long working hours,

- Post-call leaves should be well balanced,

- Supervision in outpatient clinics should be provided,

- Generalized national qualification exams should be compatible with ENTOG member countries,

- A standardized national logbook should be formed to standardize training,

- Rotations should be functional, and external rotations should be implemented in university hospitals.

\section{Conclusion}

OBGYN has been the top preferred residency position in Turkey in the past. OBGYN trainees' career expectations and future plans appear to be changing. Extremely long work hours, excessive workload, high number of duties per month, and no supervision in outpatient clinics were found to be the major issues. Identifying these issues is critical to improve the quality of training and demand/supply balance for residency.

\section{Ethics}

Ethics Committee Approval: Not applicable.

Informed Consent: Informed consent was obtained from these trainees.

Peer-review: Externally peer-reviewed.

\section{Authorship Contributions}

Concept: A.K., S.E., Design: S.E., M.Y., B.C., Data Collection or Processing: M.Y., B.C., Analysis or Interpretation: S.E., O.İ., iterature Search: S.E., O.İ., Writing: S.E., M.Y., O.İ.

Conflict of Interest: No conflict of interest was declared by the authors.

Financial Disclosure: The authors declared that this study received no financial support.

\section{References}

1. Nunes F, Bevan R. The implementation of a European Network of Trainees in Obstetrics and Gynaecology (ENTOG). Eur J Obstet Gynecol Reprod Biol 1999;87:199-201.

2. Barber MD, Maher C. Apical prolapse. Int Urogynecol J 2013;24:1815-33.

3. Kafadar YT, Gode F, Demir C, Baloglu A. Current challenges of the gynecology assistants in Turkey. Turk J Obstet Gynecol 2013; 10:37-41.

4. Tuncer AM, Tatar M, Şahin İ. University hospitals in Turkey: Structural crisis in financing or consequence of mismanagement? Journal of Hospital Administration 2017;6:52.

5. www.osym.gov.tr.

6. Stonehocker J, Muruthi J, Rayburn WF. Is There a Shortage of Obstetrician-Gynecologists? Obstet Gynecol Clin North Am 2017;44:121-32.

7. Pulcrano M, Evans SR, Sosin M. Quality of Life and Burnout Rates Across Surgical Specialties: A Systematic Review. JAMA Surg 2016;151:970-8.

8. Becker JL, Milad MP, Klock SC. Burnout, depression, and career satisfaction: cross-sectional study of obstetrics and gynecology residents. Am J Obstet Gynecol 2006;195:1444-9.

9. Alston MJ, Autry AM, Wagner SA, Winkel A, Allshouse AA, Stephenson-Famy A. Obstetricians and Gynecologists of the Future: A Survey of Medical Students Applying to Residency. Obstet Gynecol 2017;130:1-7.

10. Rodríguez D, Christopoulos P, Martins N, Pärgmäe P, Werner HM. Working conditions survey and trainees situation: new approach to auditing the situation of European trainees in obstetrics and gynaecology ten years later. Eur J Obstet Gynecol Reprod Biol 2009;147:130-4.

11. Prabhu AM, Chiang S, Schiff MA, Landis CA, Lee K, Reed SD. Effects of home call on obstetrics and gynecology resident sleep patterns. Am J Obstet Gynecol 2016;214:409-10.

12. Alston MJ, Metz TD, Fothergill R, Meg Autry A, Wagner SA, Allshouse AA, et al. Factors Influencing Residency Program Selection by Medical Students Pursuing Obstetrics and Gynecology. J Grad Med Educ 2017;9:123-7.

13. Cadish LA, Muffly TM. Recent Ob/Gyn Residency Graduates' Experience With Hysterectomy. Obstetrics \& Gynecology 2018; 132:46S.

14. Alston MJ, Ehrig J, Autry AM, Wagner SA, Kohl-Thomas BM, Allshouse AA, et al. Career Expectations of Obstetrics and Gynecology Residents and Future Residents. Obstet Gynecol 2018;132:1-7.

15. Glaser LM, Alvi FA, Milad MP. Trends in malpractice claims for obstetric and gynecologic procedures, 2005 through 2014. Am J Obstet Gynecol 2017;217:340.e1-340.e6.

16. Blanchard MH, Ramsey PS, Gala RB, Gyamfi Bannerman C, Srinivas SK, Hernandez-Rey AE. Impact of the medical liability crisis on postresidency training and practice decisions in obstetricsgynecology. J Grad Med Educ 2012;4:190-5. 